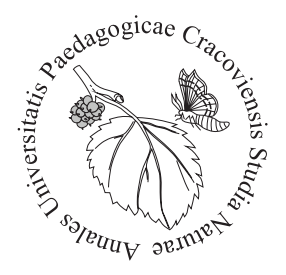

Saikat Kumar Basu' ${ }^{1}$, William Cetzal-Ix² ${ }^{2}$ Alminda Magbalot-Fernandez ${ }^{3}$, Peiman Zandi ${ }^{4,5}$

${ }^{1}$ PS Lethbridge, AB Canada T1J 4B3

${ }^{2}$ Tecnológico Nacional de México, Instituto Tecnológico de Chiná. Calle 11 entre 22y 28, Colonia Centro Chiná 24050. Campeche, México; ${ }^{*}$ rolito22@hotmail.com ${ }^{3}$ School of Agriculture \& Food Technology, The University of the South Pacific, Private Mail Bag, Apia, Samoa

${ }^{4}$ International Faculty of Applied Technology, Yibin University, Yibin, Sichuan, 644600, P. R. China ${ }^{5}$ Institute of Environment and Sustainable Development in Agriculture, Chinese Academy of Agricultural Sciences, Beijing 100081, P. R. China

\title{
Traditional and novel proposals for the protection of endangered pollinating insects
}

An alarming decline has been observed in insect pollinator populations and subpopulations living in various ecosystems across the planet. Among insect pollinators, bees have been the most impacted. Native populations of several endemic (indigenous) bees are showing very serious decline, being pushed almost to the verge of extinction (Tollefson, 2019). Many countries around the world have documented elevated declines in bee populations, including China, Brazil, North America and Europe. The reasons underlying such a worrying decline are not well-known. Numerous factors, such as: excessive pollution, rapid rises in aggressive industrial agriculture, excess use of various toxic synthetic chemicals in agriculture, transformation in land use policies and practices, Colony Collapse Disorder (CCD), poor immunity, loss of vigour in genetic strains, genetic bottlenecks, a rise in various parasitic diseases and a lack of suitable foraging plants (melliferous vegetation) and adequate nutrition (inadequate supply of nectar and pollen across different seasons), are attributed to this rapid decline of pollinator insect populations, including bees and bumblebees (Gallai et al., 2009; Potts et al., 2010; Henry et al., 2012). The scenario is extremely disturbing as it is inter-connected with the future agricultural productivity, food security and stability of our natural or semi-natural global ecosystems. It is therefore essential to formulate a comprehensive, long-term, cost efficient and sustainable model for conserving insect pollinators to secure the future of two important global areas, namely: agriculture (including apiculture) and forestry (Basu, Cetzal-Ix, 2018 a, b, 2019; Coh-Martinez et al., 2019).

The wide diversity of flowering plants - both dicotyledonous and monocotyledon- 
ous plants (which include a vast majority of our food and industrial crops), are directly or indirectly dependent on natural pollinators through cross-pollination necessary for their generative reproduction. Natural pollinators include not only insects like bees (such as honeybees and/or native bees), bumblebees, moths and butterflies (Fig. 1-2 - Appendix 1) and some species of pollination-friendly ants, wasps, beetles and flies but certain species of slugs and snails, birds (humming birds, sun birds, parakeets, etc.) and mammals (such as different species of bats). Several species other than insects, like reptiles (lizards) and amphibians, are also suspected of being active agents of cross-pollination. A rich diversity of animal species, not only insects, are involved in the process of cross-pollination (Robinson et al., 2017). In fact, honey bees are responsible for only a third of the pollination of crops and a very small percentage of pollination of wild plants. There are many other insects that carry out this work and they are also in trouble - their population and subpopulations across the planet are decreasing alarmingly (Kremen et al., 2007). However, the native bees, bumblebees (Tab. 1 - Appendix 2) and honey bees are the most endangered (Garibaldi et al., 2013; Kleijn et al., 2015).

The gradual reduction of insect pollinator populations is alarming since they have direct implications for our future and the stability of fragile global ecosystems (Ripple et al., 2017). They play a key role in maintaining plant diversity. The local extinction of even a single species of pollinator can lead to the disappearance of some plant species populations (Lever et al., 2014; Embry, 2018). Thus, it is critical to focus on developing a comprehensive, but sustainable and affordable, conservation policy for insect pollinators for different countries. If the human factor is not included in the conservation equation for protecting the insect pollinators the conservation policy cannot be successful in any part of the planet. Hence, it is essential that we develop a low-cost and low-maintenance, farmer- and environment-friendly simple "green approach" that can help save the endangered pollinator populations without stressing economies.

The aim of this study is to briefly review traditional and novel methods for protecting pollinating insects and to propose the creation of special refuges - "Pollinator Sanctuaries", that condition suitable habitats and an abundance of food for bees, bumblebees and other pollinators.

\section{Traditional ways to protect pollinators}

Traditional ways of protecting insects and other pollinators are classified in terms of species protection or biotope protection. The disappearance of biotopes of a given species is the most common reason for quantity decline and, consequently, extinction. Inclusion of a species on a list prohibiting their destruction by individuals is usually not sufficient to safeguard its durability if the biotope in which it occurs is transformed. 
Therefore, modern species protection emphasizes the protection of habitats of species, not just the species themselves. It is currently thought that the most effective method is the preservation of all natural diversity in the context of preserving rich gene pools in changing environmental conditions (Pickett, Cadenasso, 2002; Gastauera et al., 2013).

In terms of risk to the richness of pollinating insects, the loss of habitats and flower resources results from structural simplification of the agricultural landscape and increased intensity of the use of arable land and grassland (Kleijn et al., 2009; Goulson et al., 2015). It is believed that the loss of uncultivated habitats (fallow lands) and increased land use are particularly harmful to rare pollinator species (Kleijn et al., 2015). The systematic loss of this type of species may contribute to the biotic homogenization of entomofauna groups (Gámez-Virués et al., 2015). Studies generally show negative relationships between the local richness of wild bees and the decreasing complexity of the landscape in terms of the reduction of natural and semi-natural habitat areas (Hendrickx et al., 2007; Scheper et al., 2013; Ekroos et al., 2020).

In the second half of the last century, the approach to protective management also gradually changed. It was once thought that the most effective way of protection was the so-called passive (conservation) protection, which is effective, but more so in preserving the resources of diversity of forest communities (Sołtys-Lelek et al., 2014), including forest pollinators (Robinson et al., 2017). In the case of semi-natural communities - xerothermic grasslands, meadows and pastures, which focus the greatest richness of pollinating insects, conservation protection leads to the overgrowth of these surfaces and the gradual elimination of light-sensitive species (Drury, Nisbet, 1973). As a result, it also significantly reduces the diversity of entomofauna (Maina et al., 2019).

Therefore, it is currently believed that in the preservation of non-forest biotopes and all the diversity associated with these habitats balanced, extensive utilitarian managements, such as moderate grazing or mowing and extensive fertilisation, are necessary. In neighbouring arable fields, it is recommended to limit the use of herbicides and other plant protection products that can harm pollinating insects (Holzschuh et al., 2007; Kleijn et al., 2009; Robinson et al., 2017; Ekroos et al., 2020). These treatments are not only important for maintaining the diversity of flowering plants but for maintaining the species richness of bees, bumblebees, butterflies and other insects. Meadows and other grasslands offer both nests and flower resources for insects for most of the growing season, unless they are used too intensively (Gathmann et. al., 1994; Albrecht et al., 2007; Batáry et al., 2010; Winfree, 2010). Grasslands support both species important for plant pollination and species requiring protection, particularly if they offer a variety of flower resources (Sutter et al., 2017). However, since many (immeasurable) factors can simultaneously affect biodiversity (Cornell, Harrison, 2014), it can be assumed that the high local intensity of land use will have an 
overriding negative impact on pollinating insects, thus limiting their diversity, despite the potential availability of resource habitat (Ekroos, Kuussaari, 2012; Kennedy et. al., 2013; Hopfenmüller et al., 2014; Ekroos et al., 2020).

\section{Innovative proposals in the protection of pollinating insects}

Since bees and other pollinators are mobile organisms, they can survive even in intensively managed landscapes, as long as there are enough semi-natural habitats for their nesting and foraging (Jabr, 2013). This may suggest that the protection of common pollinating insects can be maintained in intensive farming systems, as long as a minimum number of semi-natural habitats are available to them (Baldock et al., 2015; Ekroos et al., 2016). These conclusions led to the emergence of new postulates important in the protection of pollinating insects in anthropogenic habitats, especially in areas of large urban agglomerations. Considering how important numerous plants pollinated by insects are for the entire human economy (Potts et al., 2016), the notion of pollinator protection in urban areas has begun to be promoted (Garbuzov, Ratnieks, 2014).

Over the last several years, building houses for insects has become popular in both city parks and green areas, in rural areas, in gardens and even on farms themselves

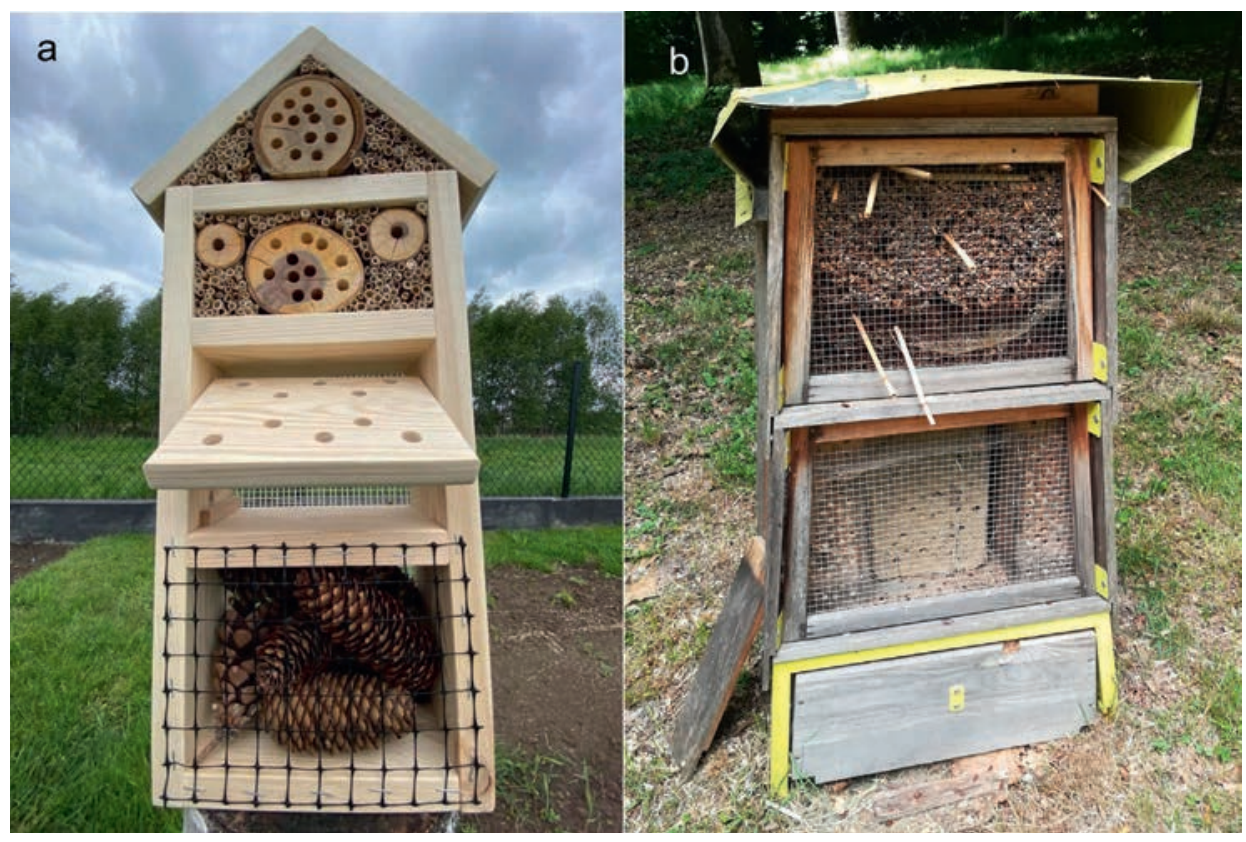

Fig. 3. An example of a house for insects of pollinating with wood (a) and mixed construction (b) (Photo. S.K Basu) 
(Falk, 2015). The construction of an insect house is very simple and can be a do-ityourself project (Fig. 3). Detailed instructions on this topic can be found in many available online sources (e.g. Carlton, 2017). The houses should be placed in a quiet, sunny and dry place. They can be made of wood or using elements of straw, reed or bricks. A "wild flower meadow", as well as a piece of un-mowed neglected lawn or planting nectaring plants, such as Erica sp., Rubus sp., Salix sp., Thymus sp., Tilia sp., attracts useful pollinating insects to them (Carvell et al., 2007; Salisbury et al., 2015). Such insect houses also have a very important didactic function; we can better get to know and understand the world of nature, and some housing structures allow for the observing the stages of insect development.

Another interesting idea for the protection of pollinating insects is the establishment of "flower meadows" in urban areas. This idea has been popular in recent years, both in Western Europe, e.g. Great Britain, France and Germany, and in Central Europe, e.g. in Poland. This type of meadow is an alternative to monotonous urban lawns, and can also be a feeding place and refuge for pollinating insects (Baldock et al., 2015). Through flowering plants, the meadow can have a positive effect on the aesthetics of the area, delighting with colours and smell (Hoylea et al., 2017). Residents can also use the meadow, and the installation of information boards about plants and insect species occurring there and the purpose of the entire undertaking can fulfil educational functions (Lindemann-Matthies, Bose, 2007). Urban "flower meadows" can be made on virtually any well-sunned surface that is not dominated by large trees. The species composition, properly selected for the type of soil, allows for the use of areas that are often degraded by humans, where it may be difficult to maintain a nice lawn (roadsides, road lanes, neighbourhoods of public transport tracks, etc.). Exemplary compositions of plant mixtures can easily be found on many online sources (Tab. 2 Appendix 2), which strongly support the idea of protection, but they are not always satisfactory in the context of the utility quality for pollinators and the length of access (Garbuzov, Ratnieks, 2014; Harmon-Threatt, Hendrix, 2015; Hicks et al., 2016). The "flower meadow" is also an economically viable alternative to city lawns. Savings arise from the caretaking of the area by limiting mowing to one or two mowing operations in a season. However, there are also opponents of this type of project, who hold that urban "flower meadows" are not ideal for protection of insects. The fact that city meadows are often in the vicinity of streets may have unintended but harmful consequences: insects attracted by plants may be more vulnerable to being hit by a car. In addition, the creation of small isolated meadows filled with "potential prey" is a sure way to attract predators (such as birds) that very quickly reduce the number of insects. Even the best mix of meadow plants selected to a given area should be cared (weeded) for the first several years to prevent expansive weeds from dominating and displacing the nectar plants (Hoylea et al., 2017); this obviously requires financial expenditure. 
Also, the use of alien species in decorative plants mixtures should be avoided as they can quickly become a threat to the native flora (Salisbury et al., 2015; Williams et al., 2011). Certainly, the idea of urban "flower meadows" is very interesting and worthy of further scientific investigation.

Another idea for protecting pollinating insects is to leave small set-aside fragments in agricultural areas where crop and meadow weeds can survive. They can be field edges or midfield balks. They can provide refuging, nesting (Svensson et al., 2000) and food for pollinators, especially when they are additionally sown with native mixtures of nectaring plants (Carvell et al., 2007; Kuussaari et al., 2011; Williams et al., 2011). Studies conducted in many countries, in Canada, the USA, Germany, and Great Britain, confirm the fact that these habitats are usually rich in flowering weed species, therefore they are a natural refuge for many pollinating insects. The richness of flower species translates directly into the richness of insects found in these areas (Carvell et al., 2007; Maina et al., 2019). Of course, it is very important that the neighbouring fields are cultivated organically, without intensive use of pesticides, as this has a direct impact on the number of insects. If agricultural lands are to be managed to preserve the diversity of species, including wild bees, maintaining diverse communities close to arable fields and/or modifying agricultural production practices in these areas can significantly improve the protection of local bee communities (Holzschuh et al., 2007; Winfree, 2010; Kennedy et. al., 2013; Maina et al., 2019).

\section{"Pollinator Sanctuaries" - our novel proposeof pollinating insects to protect}

Our proposal is a combination of the concept of flower meadows and the creation of areas separated from agricultural use in order to increase the resource of wild nectar flowers. We propose the creation of "Pollinator Sanctuaries", which will be simultaneously gardens and habitats for pollinating insects. "Pollinator Sanctuaries" can occur in the form of small plots, placed in various, normally unused places, e.g. along highways, boulevards, avenues, parks, gardens and lawns, wetland areas and around perimeters of large and small golf courses (Basu, Cetzal-Ix, 2017; Martínez-Puc et al., 2018). Those places will be sown with locally adapted "plant mixes" consisting of local honey-bearing plants (such as: Fabaceae: Lotus corniculatus L. Fig. 1a, Medicago sativa L. Fig. 1c, Vicia villosa Roth Fig. 2f; Asteraceae: Tripleurospermum inodorum (L.) Sch. Bip. Fig. 2d - Appendix 1) and pollinator-friendly acclimatised annual/biennial/perennial forage crop species (such as Asteraceae: Gaillardia sp., Fig. 1b, Echinops sphaerocephalus L., Fig. 1d, Echinacea purpurea L., Fig. 2e; Brassicaceae: Brassica napus L. Fig. 2c; and Hydrophyllaceae: Phacelia sp., Fig. 2a, b - Appendix 1), in various proportions used in agriculture. An important step in achieving that goal will be to establish "Pollinator Sanctuaries" across different agro-climatic zones. 
Plant species selected for the mix must be flowering in sequence, one after another, to extend the pollinator (bees) foraging period and provide them with an adequate supply of nectar and pollen. Plants mixes need to be developed based on appropriate agronomic parameters of the growing region and on local agro-climatic conditions, keeping in mind the local pollinator diversity and their preferences. Plant mixes constituting only native wildflowers, currently available commercially, are not a viable option due to their poor adaptability to local agronomic conditions, high yield fluctuations (based on locality and annual production variation) and high production cost. Development of suitable, environment-friendly plant mixes for various agro-climatic regions could therefore provide a long-term, low-cost and sustainable measure for conserving endangered pollinator insects (Basu, Cetzal-Ix, 2017; Basu, 2019).

This model targets several trophic levels within a natural or artificial ecosystem to conserve multiple species simultaneously in addition to local pollinator insects thereby efficiently protecting and enriching local biodiversity (Robinson et al., 2017; Basu, Cetzal-Ix, 2018 a, b). In this way, a "Pollinator Sanctuary" would not only attract pollinator insects but other species of insects and small passerine birds and then raptors that survive on other birds and rodents that take refuge in such ecosystems. Different birds, small or medium sized mammals, amphibians and reptiles are all drawn to such natural ecosystems, providing a multiple tier or multiple trophic level dynamic ecosystem operating within just a few years of establishment at an extremely low and affordable cost requiring only simple management (Basu, 2019).

The proposed model has been in use in Canada for the enhancement of local biodiversity. The model not only helps pollinator insect conservation but at the same time the can provide cover crops, used in promoting soil health, in phytoremediation, in transformation of agriculturally non-suitable areas into ecologically productive natural ecosystems units, as grazing area for pasture animals, in maintenance of pasture and rangelands, in crop rotation, as organic agriculture, in biomass generation and, last but not least, in local biodiversity enrichment. Our proposed model is simple and nature-based and does not interfere or put any negative pressure on the local economy (Basu, Cetzal-Ix, 2017). Thus, it has the potential for integrating economy with ecology while protecting species and enhancing biodiversity of small island nations through a simple nature-based approach.

\section{Conclusions}

In face of mass extinction of pollinating insects in many regions of the world, all proposals for their protection, both the older, classic as well as the new, should be comprehensively used. Numerous agri-environmental programs that directly or indirectly 
protect pollinating insects seem to help in this regard. Of course, attention should be paid to the local conditions and an effort made to try to adapt the selection of appropriate methods and protective strategies to them as much as possible. Universal social education is also important in this respect, which should emphasise, especially in isolated (island) areas, the absolute need to protect the biological resources of local flora and thus local entomofauna. This is an essential element in preserving biological resources, of which we are only a small part, in times of the highest anthropo-pressure to date.

\section{Acknowledgement}

The authors thank of ESBEC Group, USA \& Performance Seed, Lethbridge, AB Canada.

\section{Conflict of interest}

The authors declare no conflict of interest related to this article.

\section{References}

Albrecht, M., Duelli, P., Müller, C., Kleijn, D., Schmid, B. (2007).The Swiss agri-environment scheme enhances pollinator diversity and plant reproductive success in nearby intensively managed farm land. Journal of Applied Ecology, 44, 813-822. https://doi.org/10.1111/j.1365-2664.2007.01306.x

Animal Diversity Web (ADW) database. Bombus. https://animaldiversity.org/accounts/Bombus/classification/

Baldock, K.C.R., Goddard, M.A., Hicks, D.M., Kunin, W.E., Mitschunas, N., Osgathorpe, L.M., Potts, S.G., Robertson, K.M., Scott, A.V., Stone, G.N., Vaughan, I.P., Memmott, J. (2015). Where is the UK's pollinator biodiversity? The importance of urban areas for flower-visiting insects. Proceedings of the Royal Society B, Biological Sciences, 282(1803), 20142849. https://doi.org/10.1098/rspb.2014.2849

Basu, S.K., Cetzal-Ix, W. (2017). Establishing Bee Sanctuaries in North America for Conserving Insect Pollinators With Special Emphasis to Native Bees. International Journal on Agricultural Sciences, 8(1), $1-8$.

Basu, S.K., Cetzal-Ix, W. (2018a). Call of the wild: Conservation of natural insect pollinators should be a priority. Biodiversity, 19, 240-243. https://doi.org/10.1080/14888386.2018.1523747

Basu, S.K., Cetzal-Ix, W. (2018b). Traditional honey collectors in the Sundarbans region and their impact on the local mangrove ecosystem and biodiversity: a case study with particular reference to the human-animal conflict. Biodiversity, 19, 248-254. https://doi.org/:10.1080/14888386.2018.1508365

Basu, S.K., Cetzal-Ix, W. (2019). A Canadian model for establishing Pollinator Sanctuaries for successful pollinator insect conservation with special emphasis to bees. NESA Newsletter, 22(10), 7-9.

Batáry, P., Báldi, A., Sárospataki, M., Kohler, F., Verhulst, J., Knop, E., Herzog, F., Kleijn, D. (2010). Effect of conservation management on bees and insect-pollinated grassland plant communities in three European countries. Agriculture, Ecosystems \& Environment, 136, 35-39. https://doi.org/10.1016/j. agee.2009.11.004

Carlton, M. (2017). How to Make and Manage a Bee Hotel: Instructions that Really Work. https://www. foxleas.com/make-a-bee-hotel.asp [updated November 2017].

Carvell, C., Meek, W.R., Pywell, R.F., Goulson, D., Nowakowski, M. (2007). Comparing the efficacy of agri-environment schemes to enhance bumble bee abundance and diversity on arable field margins. Journal f Applied Ecology, 44, 29-40. https://doi.org/10.1111/j.1365-2664.2006.01249.x

Coh-Martinez, M.E., Cetzal-Ix, W., Martinez-Puc, J.F., Basu, S.K., Noguera-Savelli, E., Cuevas, M.J. 
(2019). Beekeepers perceptions on diversity and flowering phenology of species with apicultural potential in the in the community of Xmabén, Hopelchén, Campeche, México. Journal of Ethnobiology \& Ethnomedicine, 15, 16. https://doi.org/10.1186/s13002-019-0296-1

Cornell, V.H., Harrison, S.P. (2014). What are species pools and when are they important? Annual Review of Ecology, Evolution, and Systematics, 45, 45-67. DOI:10.1146/annurev-ecolsys120213-091759.

Dąbrowska, A., Kulik, M. (2020). Projekt naukowy „Eąki kwietne” realizowany przez Wody Polskie (Scientific project "Flower meadows" implemented by Polish Waters). https://stopsuszy.pl/projekt-laki-kwietne-realizowany-przez-wody-polskie/ [In Polish]

Drury, W.H., Nisbet, I.C.T. (1973). Succession. Journal of the Arnold Arboretum, 54(3), 331-368.

Ekroos, J., Kleijn, D., Batáry, P., Albrech,t M., Báldid, A., Blüthgen, N., Knop, E., Kovács-Hostyánszki, A., Smith, H.G. (2020). High land-use intensity in grasslands constrains wild bee species richness in Europe. Biological Conservation, 241, 108255. https://doi.org/10.1016/j.biocon.2019.108255

Ekroos, J., Kuussaari, M. (2012). Landscape context affects the relationship between local and landscape species richness of butterflies in semi-natural habitats. Ecography, 34, 232-238. https://doi. org/10.1111/j.1600-0587.2011.07005.x

Ekroos, J., Ödman, A.M., Andersson, G.K.S., Birkhofer, K., Herbertsson, L., Klatt, B.K., Olsson, O., Olsson, P.A., Persson, A.S., Prentice, H.C., Rundlöf, M., Smith, H.G. (2016). Sparing land for biodiversity at multiple spatial scales. Frontiers in Ecology and Evolution, 3, 145. https://doi.org/10.3389/ fevo.2015.00145

Ellis, A., Myers, M., Ricketts, S.S., Taylor, H. (2015). Do pollinators contribute to nutritional health? Plos One, 10(1), 114805. https://doi.org/10.1371/journal.pone.0114805

Embry, P. (2018). Our native bees: North America's endangered pollinators and the fight to save them hardcover. USA: Oxford University Press on behalf of the Entomological Society of America.

Falk, S. (2015). Field Guide to the Bees of Great Britain and Ireland (Field Guides). UK: Bloomsbury Publishing PLC. $432 \mathrm{pp}$.

Flora Polski atlas-roslin.pl. Rośliny naczyniowe dziko rosnace, uprawne, ozdobne gruntowe, mszaki (Polish flora atlas-roslin.pl. Vascular plants growing wild, cultivated, ornamental, ground, bryophytes). https:// www.atlas-roslin.pl/ [In Polish]

Gallai, N., Salles, J.M., Settele, J., Vaissière, B.E. (2009). Economic valuation of the vulnerability of world agriculture confronted with pollinator decline. Ecological Economics, 68(3), 810-821. https://doi. org/10.1016/j.ecolecon.2008.06.014

Gámez-Virués, S., Perović, D.J., Gossner, M.M., Börschig, C., Blüthgen, N., De Jong, H., Simons, N.K., Klein, A-M., Krauss, J., Maier, G., Scherber, C., Steckel, J., Rothenwöhrer, C., Steffan-Dewenter, I., Weiner, C.N., Weisser, W., Werner, M., Tscharntke, T., Westphal, C. (2015). Landscape simplification filters species traits and drives biotic homogenization. Nature Communications, 6, 8568. https://doi. org/: $10.1038 /$ ncomms9568

Garbuzov, M., Ratnieks, F.L.W. (2014). Quantifying variation among garden plants in attractiveness to bees and other flower-visiting insects. Functional Ecology, 28(2), 364-374. https://doi.org/10.1111/13652435.12178

Garibaldi, L., Steffan-Dewenter, I., Winfree, R., Aizen M., Bommarco, R., Cunningham, S. (2013). Wild pollinators enhance fruit set of crops regardless of honey bee abundance. Science, 339, 1608-1611. https://doi.org/10.1126/science.1230200

Gastauera, M., Treinb, L., Meira-Netoa, J.A.A., Schumacherb, W. (2013). Evaluation of biotope's importance for biotic resource protection by the Bonner Approach. Ecological Indicators, 24, 193-200. https://doi.org/10.1016/j.ecolind.2012.06.014 
Goulson, D., Nicholls, E., Botías ,C., Rotheray, E.L. (2015). Bee declines driven by combined stress from parasites, pesticides, and lack of flowers. Science, 347(6229), 1255957. https://doi.org/10.1126/science. 1255957

Harmon-Threatt, A.N., Hendrix S.D. (2015). Prairie restorations and bees: the potential ability of seed mixes to foster native bee communities. Basic and Applied Ecology, 16(1), 64-72. https://doi. org/10.1016/j.baae.2014.11.001

Hendrickx, F., Maelfait, J.-P., Van Wingerden, W., Schweiger, O., Speelmans, M., Aviron, S., Augenstein, I., Billeter, R., Bailey, D., Bukacek, R., Burel, F., Diekötter, T., Dirksen, F., Herzog, F., Liira, J., Roubalova, M., Vandomme, V., Bugter, R. (2007). How landscape structure, land use intensity and habitat diversity affect components of total arthropod diversity in agricultural landscapes. Journal of Applied Ecology, 44(2), 340-351. https://doi.org/10.1111/j.1365-2664.2006.01270.x

Henry, M., Béguin, M., Requier, M., Rollin, O., Odoux, J.-F., Aupine, P., Aptel, J., Tchamitchian, S., Decourtye, A. (2012). A common pesticide decreases foraging success and survival in honey bees. Science, 336(6079), 348-350. https://doi.org/10.1126/science.1215039

Hicks, D.M., Ouvrard, P., Baldock, K.C.R., Baude, M., Goddard, M.A., Kunin, W.E., Mitschunas, N., Memmott, J., Morse, H., Nikolitsi, M., Osgathorpe, L.M., Potts, S.G., Robertson, K.M., Scott, A.V., Sinclair, F., Westbury, D.B., Stone, G.N. (2016). Food for Pollinators: Quantifying the Nectar and Pollen Resources of Urban Flower Meadows. Plos One, 11(6), e0158117. https://doi.org/10.1371/journal. pone. 0158117

Holzschuh, A., Steffan-Dewenter, I., Kleijn D., Tscharntke ,T. (2007). Diversity of flower-visiting bees in cereal fields: effects of farming system, landscape composition and regional context. Journal $f$ Applied Ecology, 44, 41-49. DOI: 10.1111/j.1365-2664.2006.01259.x

Hopfenmüller, S., Steffan-Dewenter I., Holzschuh A. (2014). Trait-specific responses to wild bee communities to landscape composition, configuration and local factors. Plos One, 9(8), e104439. https://doi. org/10.1371/journal.pone.0104439

Hoylea, H., Jorgensena, A., Warrenb, P., Dunnetta, N., Evansb, K. (2017). "Not in their front yard" The opportunities and challenges of introducing perennial urban meadows: A local authority stakeholder perspective. Urban Forestry \& Urban Greening, 25, 139-149. https://doi.org/10.1016/j. ufug.2017.05.009

IUCN - International Union for Conservation of Nature (2020). The IUCN Red List of Threatened Species. Version 2019-3. https://www.iucnredlist.org.

Jabr, F. (2013). The Mind-Boggling Math of Migratory Beekeeping. Scientific American, https://www.scientificamerican.com/article/migratory-beekeeping-mind-boggling-math/.

Kennedy, C.M., Lonsdorf, E., Neel, M.C., Williams, N.M., Ricketts, T.H., Winfree, R., Bommarco, R., Brittain, C., Burley, A.L., Cariveau, D., Carvalheiro, L.G., Chacoff, N.P., Cunningham, S.A., Danforth, B.N., Dudenhöffer, J.-H., Elle, E., Gaines, H.R., Garibaldi, L.A., Gratton, C., Holzschuh, A., Isaacs, R., Javorek, S.K., Jha, S., Klein, A.M., Krewenka, K., Mandelik, Y., Mayfield, M.M., Morandin, L., Neame, L.A., Otieno, M., Park, M., Potts, S.G., Rundlöf, M., Saez, A., Steffan-Dewenter, I., Taki, H., Viana, B.F., Westphal, C., Wilson J.K., Greenleaf, S.S., Kremen, C. (2013). A global quantitative synthesis of local and landscape effects on wild bee pollinators in agroecosystems. Ecology Letters, 16(5), 584-599. https://doi.org/10.1111/ele.12082

Kleijn, D., Kohler, F., Báldi, A., Batáry, P., Concepción, E.D., Clough, Y., Díaz, M., Gabriel, D., Holzschuh, A., Knop, E., Kovács, A., Marshall, E.J.P., Tscharntke, T., Verhulst, J. (2009). On the relationship between farmland biodiversity and land-use intensity in Europe. Proceedings of the Royal Society B, Biological Sciences, 276, 903-909. https://doi.org/10.1098/rspb.2008.1509

Kleijn, D., Winfree, R., Bartomeus, I., Carvalheiro, L.G., Henry, M., Isaacs, R. (2015). Delivery of crop pollination services is an insufficient argument for wild pollinator conservation. Nature Communications, 6, 7414. https://doi.org/7414 10.1038/ncomms8414 
Kremen, C., Williams, N.M., Aizen, M.A., Gemmill-Herren, B., LeBuhn, G., Minckley, R., Packer, L., Potts, S.G., Roulston, T.A., Steffan-Dewenter, I., Vázquez, D.P., Winfree, R., Adams, L., Crone, E.E., Greenleaf, S.S., Keitt, T.H., Klein, A.-M., Regetz, J., Ricketts, T.H. (2007). Pollination and other ecosystem services produced by mobile organisms: a conceptual framework for the effects of land-use change. Ecology Letters, 10(4), 299-314. https://doi.org/10.1111/j.1461-0248.2007.01018.x

Kuussaari, M., Hyvönen, T., Härmä, O. (2011). Pollinator insects benefit from rotational fallows. Agriculture, Ecosystems \& Environment, 143(1), 28-36. https://doi.org/10.1016/j.agee.2011.03.006

Lever, J.J., Nes, E.H., Scheffer, M., Bascompte, J. (2014). The sudden collapse of pollinator communities. Ecology Letters, 17(3), 350-359. https://doi.org/10.1111/ele.12236

Lindemann-Matthies, P., Bose, E. (2007). Species richness, structural diversity and species composition in meadows created by visitors of a botanical garden in Switzerland. Landscape and Urban Planning, 79(3-4), 298-307. https://doi.org/10.1016/j.landurbplan.2006.03.007

Maina, A.R., Webbba, E.B., Goynea, K.W., Mengelc, D. (2019). Field-level characteristics influence wild bee functional guilds on public lands managed for conservation. Global Ecology and Conservation, 17, e00598. https://doi.org/10.1016/j.gecco.2019.e00598

Martínez-Puc, J.F., Cetzal-Ix, W., González-Valdivia, N.A., Casanova-Lugo, F., Basu, S.K. (2018). Characterization of beekeeping activity in the main municipalities of honey production in Campeche, Mexico. Journal of the Selva Andina Animal Science, 5(1), 45-53. [In Spanish]

Ollerton, J., Winfree, R., Tarrant, S. (2011). How many flowering plants are pollinated by animals? Oikos, 120(3), 321-326. https://doi.org/10.1111/j.1600-0706.2010.18644.x

Pickett, S.T.A., Cadenasso, M.L. (2002). The ecosystem as a multidimentional Concept: Meaning, Model, and Metaphor. Ecosystems, 5, 1-10. https://doi.org/10.1007/s10021-001-0051-y

Potts, S., Biesmeijer, J., Kremen, C., Neumann, P, Schweiger, O., Kunin, W. (2010). Global pollinator declines: trends impacts and drivers. Trends in Ecology \& Evolution, 256, 345-353. https://doi. org/10.1016/j.tree.2010.01.007

Potts, S.G., Imperatriz-Fonseca, V., Ngo, H.T., Aizen, M.A., Biesmeijer, J.C., Breeze, T.D., Dicks, L.V., Garibaldi, L.A., Hill, R., Settele, J., Vanbergen, A.J. (2016). Safeguarding pollinators and their values to human well-being. Nature, 540, 220-229. https://doi.org/10.1038/nature20588

Ripple, W.J., Wolf, C., Newsome, T.M., Galetti, M., Alamgir, M., Crist, E., Mahmoud, M.I., Laurance, W.F. (2017). World scientists' warning to humanity: A second notice. BioScience, 67, 1026-1028. https:// doi.org/10.1093/biosci/bix125

Robinson, S., Cetzal-Ix, W., Basu, S.K. (2017). Wild bee decline and conservation in North America. Annales Universitatis Paedagogicae Cracoviensis Studia Naturae, 2, 159-169. https://doi. org/10.24917/25438832.2.12

Scheper, J., Holzschuh, A., Kuussaari, M., Potts, S.G., Rundlöf, M., Smith, H.G., Kleijn, D. (2013). Environmental factors driving the effectiveness of European agri-environmental measures in mitigating pollinator loss - a meta-analysis. Ecology Letters, 16, 912-920. https://doi.org/10.1111/ele.12128

Sołtys-Lelek, A., Barabasz-Krasny, B., Możdżeń, K. (2014). Selected aspects of the protection of biotopes on the example of the Ojców National Park (Southern Poland). Annales Universitatis Paedagogicae Cracoviensis Studia ad Didacticam Biologiae Pertinentia, 4(174), 99-117.

Sutter, L., Jeanneret, P., Bartual, A.M., Bocci, G., Albrecht, M. (2017). Enhancing plant diversity in agricultural landscapes promotes both rare bees and dominant crop-pollinating bees through complementary increase in key floral resources. Journal of Applied Ecology, 54, 1856-1864. https://doi. org/10.1111/1365-2664. 12907

Svenssona, B., Lagerlöfa, J., Svensson, B.G. (2000). Habitat preferences of nest-seeking bumble bees (Hymenoptera: Apidae) in an agricultural landscape. Agriculture, Ecosystems \& Environment, 77(3), 247-255. https://doi.org/10.1016/S0167-8809(99)00106-1 
Tollefson, J. (2019). Humans are driving one million species to extinction. Nature, 569, 171. https://doi. org/10.1038/d41586-019-01448-4

Williams, N.M., Cariveau, D., Winfree, R., Kremen, C. (2011). Bees in disturbed habitats use, but do not prefer, alien plants. Basic and Applied Ecology, 12(4), 332-341. https://doi.org/10.1016/j.baae. 2010.11.008

Winfree, R. (2010). The conservation and restoration of wild bees. Annals of the New York Academy of Sciences, 1195, 169-197. https://doi.org/10.1111/j.1749-6632.2010.05449.x 


\section{Appendix 1}
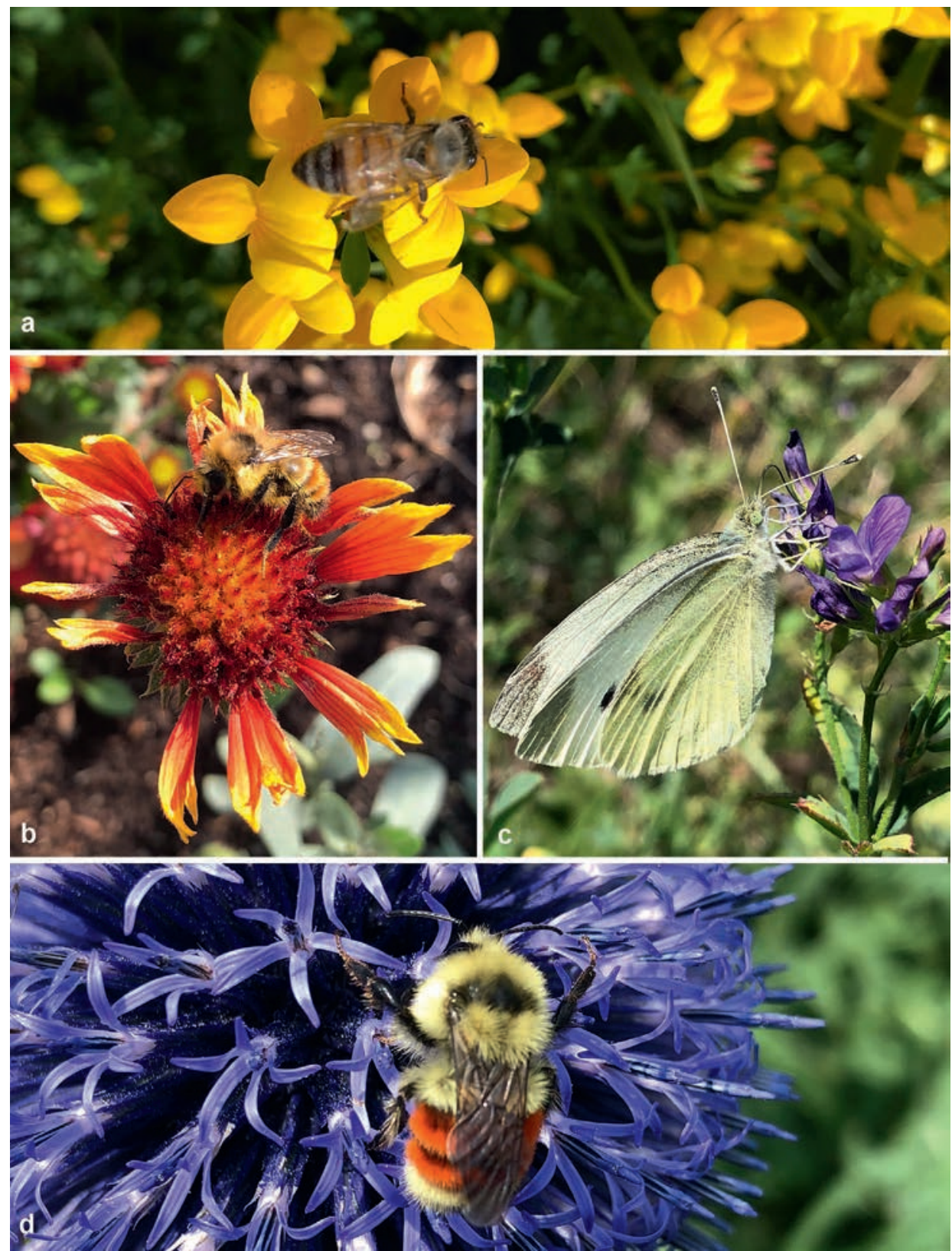

Fig 1. Insect pollinators: a - A honey bee (Apis mellifera L.) collecting pollen and nectar from flowers of Bird's foot trefoil (Lotus corniculatus L.); b - A brown bellied bumblebee (Bombus griseocollis D. Geer) foraging on blanket flower (Gaillardia sp.); c - A Western white butterfly (Pontia occidentalis Reakirt) foraging on alfalfa (Medicago sativa L.) flowers; $\mathrm{d}$ - An Orange belted bumblebee or tricoloured bumblebee (Bombus ternarius Say) foraging on flowers of showy globe thistle (Echinops sphaerocephalus L.) (Photo. S.K Basu) 

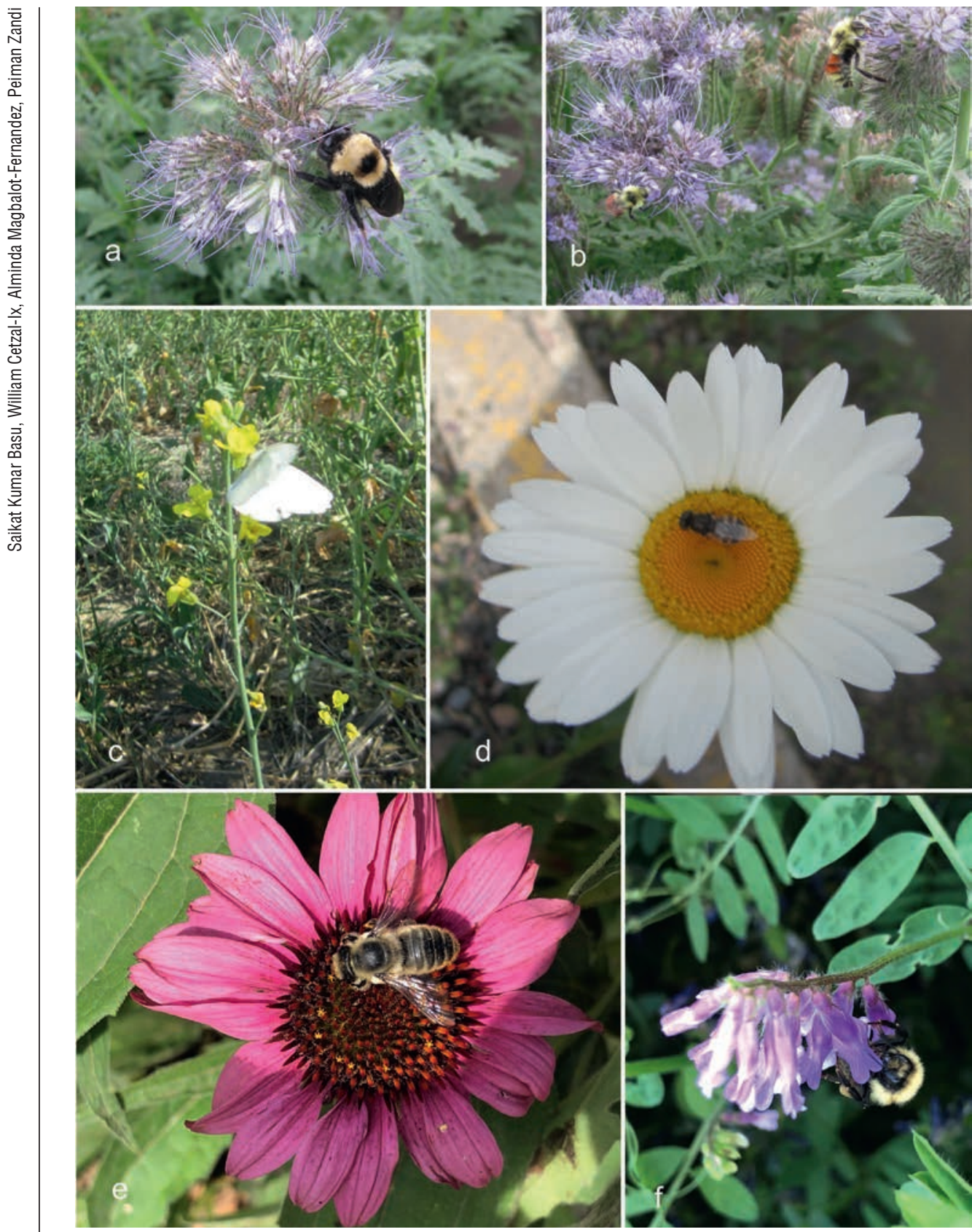

Fig. 2. Insect pollinators cont.: a - A large Nevada bumblebee (Bombus nevadensis Cresson) foraging on Scorpion weed (Phacelia sp.); b - Hunt's bumblebees (B. huntii Greene) foraging on Scorpion weed (Phacelia sp.); c - A Western checkered butterfly (Pontia protodice Boisduval \& Le Conte) foraging on canola (Brassica napus L.); d - A Stratiomyid fly visiting scentless chamomile (Tripleurospermum inodorum (L.) Sch. Bip.); e - A honey bee (Apis mellifera L.) foraging on purple cone flower (Echinacea purpurea L.); f - A bumblebee (Bombus sp.) foraging on hairy vetch (Vicia villosa Roth) flower (Photo. S.K Basu) 
Tab. 1. Endangered or threatened bumblebees species in North America according to IUCN (2020); RLC = IUCN - Red List of Threatened Species, CR - Critically Endangered, LC - Least Concern, EN - Endangered, VU - Vulnerable, DD - Data Deficient; nomenclature of animal species added according to Animal Diversity Web...

\begin{tabular}{|c|c|c|c|c|}
\hline Taxa & $\begin{array}{l}\text { Population } \\
\text { trend }\end{array}$ & RLC & Geographic range & Elevation $[\mathrm{m}]$ \\
\hline Bombus affinis Cresson & Decreasing & CR & Canada & - \\
\hline B. appositus Cresson & Unknown & $\mathrm{LC}$ & Canada, United States & - \\
\hline B. bimaculatus Cresson & Stable & $\mathrm{LC}$ & Canada, United States & - \\
\hline B. borealis Kirby & Stable & $\mathrm{LC}$ & Canada, United States & - \\
\hline $\begin{array}{l}\text { B. brachycephalus Han- } \\
\text { dlirsch }\end{array}$ & Decreasing & EN & $\begin{array}{l}\text { Mexico, El Salvador, Guatemala, } \\
\text { Honduras }\end{array}$ & $300-2800$ \\
\hline B. caliginosus Frison & Decreasing & VU & Canada, United States & - \\
\hline B. centralis Cresson & Stable & $\mathrm{LC}$ & Canada, United States & - \\
\hline B. citrinus Smith & Stable & $\mathrm{LC}$ & Canada, United States & - \\
\hline B. ephippiatus Say & Stable & $\mathrm{LC}$ & $\begin{array}{l}\text { Mexico, El Salvador, Guatemala, } \\
\text { Honduras, Nicaragua, Costa Rica, } \\
\text { Panama }\end{array}$ & $0-3595$ \\
\hline B. fervidus Fabricius & Decreasing & VU & Canada, United States, Mexico & - \\
\hline B. flavifrons Cresson & Stable & $\mathrm{LC}$ & Canada, United States & - \\
\hline B. franklin Frison & Decreasing & CR & United States & - \\
\hline B. fraternus Smith & Decreasing & $\mathrm{EN}$ & United States & - \\
\hline B. frigidus Smith & Stable & $\mathrm{LC}$ & Canada, United States & - \\
\hline B. griseocollis De Geer & Stable & $\mathrm{LC}$ & Canada, United States & - \\
\hline B. haueri Handlirsch & Decreasing & EN & Mexico & $1025-2700$ \\
\hline B. huntii Greene & Decreasing & $\mathrm{LC}$ & Canada, United States, Mexico & - \\
\hline $\begin{array}{l}\text { B. macgregori Labougle } \\
\text { \& Ayala }\end{array}$ & Stable & $\mathrm{LC}$ & Mexico, Guatemala & $1250-3260$ \\
\hline B. medius Cresson & Decreasing & VU & Mexico, El Salvador, Nicaragua & $700-2500$ \\
\hline B. melanopygus Nylander & Stable & $\mathrm{LC}$ & Canada, United States & - \\
\hline B. mexicanus Cresson & Decreasing & VU & $\begin{array}{l}\text { Mexico, El Salvador, Guatemala, } \\
\text { Honduras, Nicaragua, Costa Rica }\end{array}$ & $0-2693$ \\
\hline B. morrisoni Cresson & Decreasing & VU & Canada, United States & - \\
\hline B. nevadensis Cresson & Stable & $\mathrm{LC}$ & Canada, United States, Mexico & $0-2741$ \\
\hline B. occidentalis Greene & Decreasing & VU & Canada, United States & - \\
\hline B. pensylvanicus De Geer & Decreasing & VU & Canada, United States, Mexico & - \\
\hline B. perplexus Cresson & Stable & LC & Canada, United States & - \\
\hline B. pullatus Franklin & Unknown & $\mathrm{DD}$ & $\begin{array}{l}\text { Mexico, Guatemala, Honduras, } \\
\text { Nicaragua, Costa Rica, Panama }\end{array}$ & $0-3400$ \\
\hline B. rufocinctus Cresson & Stable & $\mathrm{LC}$ & Canada, United States & - \\
\hline B. sandersoni Franklin & Stable & $\mathrm{LC}$ & Canada, United States & - \\
\hline B. sitkensis Nylander & Stable & $\mathrm{LC}$ & Canada, United States & - \\
\hline $\begin{array}{l}\text { B. steindachneri Han- } \\
\text { dlirsch }\end{array}$ & Decreasing & $\mathrm{EN}$ & Mexico & $0-2600$ \\
\hline
\end{tabular}




\begin{tabular}{llllc} 
B. suckleyi Greene & Decreasing & CR & Canada, United States & - \\
B. sylvicola Kirby & Stable & LC & Canada, United States & - \\
$\begin{array}{l}\text { B. ternarius Say } \\
\text { B. terricola Kirby }\end{array}$ & Stable & LC & Canada, United States & - \\
$\begin{array}{l}\text { B. trinominatus Dalla } \\
\text { Torre }\end{array}$ & Stable & LC & Mexico, Guatemala & - \\
$\begin{array}{l}\text { B. vagans Smith } \\
\text { B. vandykei Frison }\end{array}$ & Stable & LC & Canada, United States & Canada \\
B. variabilis Cresson & Decreasing & CR & $\begin{array}{l}\text { Canada, United States, Mexico, } \\
\text { B. vosnesenskii } \text { Radosz- }\end{array}$ & - \\
kowski & Stable & LC & Canada, United States & -200 \\
B. weisi Friese & Stable & LC & Mexico, El Salvador, Honduras, & - \\
\hline
\end{tabular}

Tab. 2. Examples of seed mixtures recommended for establishing flower meadows in Central Europe (Sources: Dąbrowska, Kulik, 2020); nomenclature of plants according Flora Polski atlas...

\begin{tabular}{|c|c|c|c|}
\hline Family & $\begin{array}{c}\text { Dry habitats, neutral or } \\
\text { alkaline soils } \\
\text { (grassland species) }\end{array}$ & $\begin{array}{l}\text { Fresh habitats, neutral } \\
\text { soils, wide pH range } \\
\text { (fresh meadows species) }\end{array}$ & $\begin{array}{c}\text { Fresh habitats of different } \\
\text { fertility (field flowers, } \\
\text { usually 1-year's) }\end{array}$ \\
\hline \multirow[t]{4}{*}{ Asteraceae } & Achillea millefolium & Achillea millefolium & Centaurea cyanus \\
\hline & Centaurea scabiosa & Centaurea jacea & Chamomilla recutita \\
\hline & Cichorium intybus & Leucanthemum vulgare & Matricaria perforata \\
\hline & - & Tragopogon pratensis & - \\
\hline \multirow[t]{2}{*}{ Apiaceae } & Daucus carota & Daucus carota & - \\
\hline & - & Pastinaca sativa & - \\
\hline Boraginaceae & Echium vulgare & - & - \\
\hline Campanulaceae & & Campanula patula & - \\
\hline \multirow[t]{2}{*}{ Caryophyllaceae } & Saponaria officinalis & - & - \\
\hline & Anthemis tinctoria & - & - \\
\hline Dipsacaceae & - & Knautia arvensis & - \\
\hline \multirow[t]{3}{*}{ Fabaceae } & - & Lotus corniculatus & Vicia villosa \\
\hline & - & Trifolium pratense & - \\
\hline & - & Vicia cracca & - \\
\hline Geraniaceae & - & Geranium pratense & - \\
\hline Lamiaceae & Salvia pratensis & - & - \\
\hline \multirow[t]{2}{*}{ Scrophulariaceae } & Verbascum nigrum & - & - \\
\hline & V. densiflorum & - & - \\
\hline Papaveraceae & - & - & Papaver rhoeas \\
\hline \multirow[t]{3}{*}{ Poaceae } & Brachypodium pinnatum & Arrhenatherum elatius & - \\
\hline & - & Festuca rubra & - \\
\hline & - & Poa pratensis & - \\
\hline Rosaceae & Agrimonia eupatora & Sanguisroba officinalis & - \\
\hline Rubiaceae & - & Galium verum & - \\
\hline
\end{tabular}




\section{Tradycyjne i nowe propozycje ochrony zagrożonych owadów zapylających}

Streszczenie

Obecnie wymieranie owadów zapylających staje się problemem ogólnoświatowym. Jest to istotne nie tylko z punktu widzenia utraty bioróżnorodności, ale ma ogromne znaczenie dla rolnictwa i gospodarki żywnościowej świata. Tradycyjne sposoby ochrony owadów i innych zapylaczy postrzega się, albo w kategoriach ochrony gatunkowej, albo ochrony biotopowej, w ich naturalnych lub półnaturalnych siedliskach. Jednak coraz częściej podejmuje się próby ochrony tej grupy owadów w środowiskach silnie zmienionych przez człowieka, jak na przykład aglomeracje miejskie i towarzysząca im infrastruktura. Istnieją też inne propozycje, np. zakładanie pewnego rodzaju upraw - „Ostoje Zapylaczy”, na niewielkich poletkach w sąsiedztwie pól uprawnych lub miejscach nie przydatnych gospodarczo. W obecnej sytuacji wszystkie propozycje ochrony, zarówno te starsze - klasyczne, jak i te nowe, powinny być stosowane w sposób kompleksowy, bo tylko to może przynieść poprawę sytuacji owadów zapylających.

Key words: bee, biodiversity, insects, methods of protection, pollination

Received: [2020.05.15]

Accepted: [2020.07.30] 